\title{
Social Entrepreneurship Orientation: Development of a Measurement Scale
}

Sascha Kraus ${ }^{1}$, Jantje Halbertstadt ${ }^{2}$, Thomas Niemand ${ }^{1}$, Eleanor Shaw ${ }^{3}$, and Pasi Syrja ${ }^{4}$

\author{
${ }^{1}$ University of Liechtenstein \\ ${ }^{2}$ Leuphana University Lüneburg \\ ${ }^{3}$ University of Strathclyde Hunter Centre for Entrepreneurship \\ ${ }^{4}$ Lappeenranta University of Technology
}

\section{Structured Abstract}

Purpose - Despite growing scholarly $\mathrm{v}$ interest in social entrepreneurs and the social enterprises which they create, few studies have examined the hybridity of social enterprises including, surprisingly, whether they adoption an entrepreneurial orientation (EO) One explanation for this may be the continuing lack of an appropriate scale measuring a social entrepreneurship orientation. This paper seeks to address this research gap by proposing an initial social entrepreneurship orientation (SEO) scale based on input from scholars in the fields of entrepreneurship and social entrepreneurship.

Design/methodology/approach - This study presented employed mixed-methods and a two stage design. In stage one a Delphi study with 18 researchers with expertise of investigating entrepreneurship and social entrepreneurship was used to generate constructs combining aspects of both social and entrepreneurial orientations. In stage two, we assessed the face validity of the derived items from the Delphi study by conducting a survey with 82 such experts.

Findings - The paper provides empirical insights into how SEO can be measured by proposing, for the first time, a 12-item scale with 4 dimensions that allows the measurement of a social entrepreneurship orientation for the first time.

Research limitations/implications - We recommend that future studies employ quantitative methods, particularly with firms exhibiting differing levels of the 'socialness' dimension which we propose and that such studies involve a variety of research informants. Statistical analysis of data collected across large sample sizes will help evaluate the reliability and validity of the scale which we propose.

Practical implications - The paper includes implications for future research based on the proposed social entrepreneurship orientation measurement scale.

Originality/value - This paper develops the first SEO scale based on empirical data collected from experts in the fields of entrepreneurship and social entrepreneurship.

Keywords: Social Entrepreneurship, Entrepreneurship Orientation, Social Entrepreneurship Orientation, Delphi Study.

Article Type: Research paper 


\section{Introduction}

Despite growing and widespread interest in, and actions which tackle social inequalities and environmental sustainability, it is acknowledged that such challenges endure and indeed may be accelerating, partly because their existence if often debated by heads of state and scientific communities (Dees, 2007; Sheehan, 2009; Schaltegger and Wagner, 2011; Halberstadt and Kraus, 2016). Social enterprises (SE) have been identified as having the potential to address such concerns. Empirical evidence of their impact together with the adoption of increasingly neo-liberal government policies matched by dwindling public expenditure on social inequalities and environmental challenges, (encouraged, for example, by President Trump's 90 Day plan), have combined to increase interest and activity in social enterprises at a global level (Grimes et al., 2013; Nicholls, 2010; Shaw and de Bruin, 2013). Simply put, as governments retreat from the provision of interventions which address social inequalities and tackle climate change and as charitable organisations find their impact and effectiveness constrained by the bureaucracy of their funders and the increasing regulation of their sector, social entrepreneurs are responding to the growing gap left in the provision of services and interventions which seek to address the structural, societal and behavioral challenges responsible for the growing divide between the world's richest and poorest and the consequences of environmental damage (Krugman, 2009. 2013; Shaw et al., 2013).

Despite their global presence and the significant research and policy attention which SE are afforded, debate concerning how best to define a social enterprise has endured since publication of early research on social entrepreneurs and social enterprises (Bourzaga and Defourny, 2001; Dees, 2007; Shaw and Cater, 2007). Common to most definitions is agreement that SE focus on a social mission and aim to address this mission by engaging in entrepreneurial behaviors and activities (Peredo and McLean, 2006; Short et al., 2009; Dacin et al., 2010; Kraus et al., 2013). Helping further still, is research emerging from the International Comparative Social Enterprise Models Project (ICSE) launched in July 2013. In their working paper, Defourney and Nyssens (2016, p. 12), argue that 'the bulk of social enterprise types or profiles can be reduced to four major SE models': entrepreneurial non-profits; public sector social enterprises, social co-operatives and social businesses. Particular to the research presented in this paper, we identify the SEO scale we propose as having most relevance to both entrepreneurial non-profits 
which Defourney and Nyssens (2016, p. 12) define as 'all non-profit organizations developing any type of earned-income business in support of their social mission' and to, social businesses (SB). In their discussion of this approach to SE, Defourney and Nyssens (2016, p. 16) consider a number of definitions ranging from what they identify as the 'strict conditions' which Yunus (2010) places on social businesses by defining them as 'a non-loss, non-dividend, market-based company, designed to address a social objective' to the 'less demanding' suggestion that SB engage in 'activities undertaken by for-profit firms to assert their corporate and social responsibility as part of the whole range of initiatives forming the wide spectrum of social entrepreneurship (Boschee and Austin, 2000). We agree with Defourney and Nyssens (2016) that this latter definition embraces corporate social responsibility which we do not regard as being a model of social business and as such we are more closely aligned with Yunus's definition of a social business (2010) which they discuss.

Typologies of social enterprise and the existence of research networks such as ICSE are indicative of growing research interests in the field of social entrepreneurship and social enterprise. A key drive for these interests is the social and environmental impact which can be generated when entrepreneurial behaviors are combined with social intentions and purposes (Drayton, 2002; Emerson, 2003; Austin et al., 2006; Nicholls, 2010; Weerawardena and Mort, 2006; Zahra et al., 2014). Burgeoning research interests in SE do however mask the early, emergent nature of knowledge and understanding of social entrepreneurs and the enterprises which they create. Indeed, it is acknowledged that social entrepreneurship and social enterprises are a novel discipline with significant potential for future research (Shaw and Carter, 2007; Shaw and de Bruin, 2013) in particular, there have been calls for more scientific enquiry to develop innovative research fields and questions concerning SE (e.g., Bacq and Janssen, 2011; Danko et al., 2011; Nicolopoulou, 2014). Such discourse has also suggested the need to consider the negative aspects of SE as well as the impact of neo-liberal politics which have created gaps in the provision of social, community and environmental services which social enterprises have stepped in to address (Dey and Staeyert, 2012; Krugman 2009; 2013; Shaw and de Bruin, 2013).

One area of research with the potential to advance understanding not only of SE but more broadly the field of entrepreneurship is the interface between entrepreneurship and SE and examinations of the applicability and relevance of entrepreneurship theories and constructs to 
the context of SE (Choi and Majumdar, 2014; Dacin et al., 2010; Dey and Steyaert, 2012). Building on this, the study presented seeks to examine whether existing research on entrepreneurial orientation (EO) provides a suitable framework that can be applied to SE.

An EO "[ $[\ldots]$ refers to the processes, practices, and decision-making activities that lead to new entry" (Lumpkin and Dess, 1996, p. 136) and has become an important and much discussed concept within entrepreneurship research (Covin and Wales, 2012; Covin and Miller, 2013). Yet while many scholars agree that SE tackle social objectives through entrepreneurial actions (Peredo and McLean, 2006; Short et al., 2009; Dacin et al., 2010; Kraus et al., 2013) and Defourny and Nyssens's (2016) typology of social enterprise, includes entrepreneurial nonprofits and social businesses which, likewise, they argue, both engage in entrepreneurial behaviors to help address social concerns the relevance and use of an EO within the context of SE has so far received only scant conceptual considerations (c.f.: Lumpkin et al., 2013; Morris et al., 2011) In particular, suitable scales measuring social entrepreneurship orientation (SEO) have so far not been developed.

The aim of this paper is to address this gap by presenting the findings of our analysis of empirical evidence used to inform the development of a set of items measuring SEO. We present the findings of a two stage study employing mixed methods. In stage one a Delphi study with 18 researchers with expertise of investigating entrepreneurship and social entrepreneurship was used to generate constructs combining aspects of both social and entrepreneurial orientations that could be used to establish the foundations of an effective SEO measurement tool. In stage two, we assessed the face validity of the derived items from the Delphi study by conducting a survey with 82 such experts.

Following this introduction we discuss the theoretical context of our study by considering first the concept of an entrepreneurial orientation and then discussing its potential relevance to social enterprises. Next, we describe our research design and expand upon the appropriateness of the Delphi study and larger survey both of which we conducted with researchers with expertise of entrepreneurship and social entrepreneurship. Following presentation and discussion of the findings to emerge from our two-stage study, we conclude with implications for practice as well as future research. 


\section{Theoretical Background}

\section{Entrepreneurial Orientation}

The concept of an entrepreneurial orientation (EO) has become central to the domain of entrepreneurship (Covin et al., 2006). As Hughes et al., (2015:119) suggest, an "EO can be defined as the nature of the decision-making mindset, behaviors and processes underpinning the firm's strategy creation practice, competitive posture and management philosophy and thus encapsulates the entrepreneurial tendencies of the firm." Correspondingly, an EO is identified as a critical competence of entrepreneurial firms, as it is regarded as a requirement of such firms' ability to identify and exploit opportunities which create value (Bouncken et al., 2016).

Miller's $(1983,2011)$ ) work has pioneered the development of the EO construct which he identified in 1983 as consisting of three dimensions: innovativeness, risk-taking, and proactiveness which collectively, characterize the entrepreneurship process and individually have encouraged multiple measurement scales. Miller conceived of innovativeness as encompassing the willingness to create something new via creativity and experimentation resulting in original or improved products, services, or processes. He saw risk-taking as bold behavior, such as venturing into fields with little information, or investing significant amounts of (own or borrowed) money and/or other resources to venture into uncertain environments. Finally, he regarded proactiveness as involving opportunity-seeking and forward-looking behavior such as actively exploiting market opportunities in a deliberate attempt to complete with other firms. . Miller (2011: 874) explained that the primary purpose of his 1983 paper had been 'to show that entrepreneurship and its drivers were different in different types of organizational configurations' but that 'if any of these elements were missing entirely, the process might be "less than entrepreneurial". Drawing on Miller (1983), Lumpkin and Dess (1996) identify two further dimensions of the EO construct: competitive aggressiveness which they see as the degree of aggressiveness a firm exhibits in its competitive orientation, and autonomy, which is related to the degree of freedom that individuals or groups within an organization have for example, in taking decisions.

The extent to which an entrepreneurial firm needs to possess all of these dimensions at a specific level or, whether these can vary has not been explicitly investigated (Rigtering et al., 2014). However this point has been much considered: as mentioned, Miller (1986) believed all three 
of his dimensions must be exhibited in some form and more recently Covin et al., 2006) concur. Likewise, Lumpkin and Dess (,1996) and Hughes and Morgan (2007) argue that the relevance of certain dimensions can be distinctively different from each other, for example, they can have differing effects of a firm's performance. Of particular relevance to our study's interest in exploring whether and to what extent an EO has relevance for social enterprises and how knowledge of this concept can be used to inform the development of a SEO, is Miller's 2011 paper. In this he writes that he 'suspected that entrepreneurial processes would manifest differently in different contexts' (2011, p. 874) and that the nature of entrepreneurship 'would vary depending on the organizational context in which it occurred‘ (p. 875).

\section{Social Entrepreneurship Orientation}

Since early studies of social enterprise (Dees, 1998; Kanter and Purrington, 1998), definitions of what constitutes a social enterprise have continued apace with much divergence amongst scholars (Brouard and Larivet, 2009; Dacin et al. 2010, Bacq and Janssen, 2011). For example, Bacq and Janssen, 2011 found differences between 12 definitions of the term SE, 18 for social enterprise, and 17 for the social entrepreneur. These and other reviews reveal that different perspectives on SE have encouraged a multiplicity of definitions, each influenced by the specific interests of researchers. For example, while some scholars define SE in terms of common character traits and motivations of social entrepreneurs (Doherty et al., 2006; Leadbeater, 1997; Thompson, 2002; Vega and Kidwell, 2007), others focus one entrepreneurial activities and the processes of achieving social equilibrium (Dees, 2001; Alvord et al., 2004).

More studies have sought to understand how definitions have changed over time (Teasdale, 2011) and to develop better categorizations of social enterprises Defourny and Nyssens (2016). In his review of evolving and widening definitions of social enterprise specifically within England, over the period 1990-2010, Teasdale (2011) identifies three specific time periods during which definitions of social enterprise were shaped by the dominant, particularly political discourse of that time: initially SE were initially regarded as a movement (1998-2001), then as a social business (2001-2005) and more recently as a part of the third sector which engages in trading activities in the pursuit of a social purpose (2005 - 2010). While hinted at in Teasdale's discussion, Dey and Seyaert (2012) and Shaw and de Bruin (2013) drew explicit attention to the lack of discussion in the mainstream SE discourse about the effects of neo-liberal policies 
on simultaneously withdrawing resources from certain markets such as to create gaps in the provision of social services while also taking measures to build capacity within a 'big society' to create social enterprises capable of addressing these gaps though socially-motivated entrepreneurial behaviours. As mentioned above, most recently, Defourny and Nyssens (2016), have developed a typology of SE which identifies 4 different categories: entrepreneurial nonprofits which are typically supported by charities and foundations; public sector social enterprises which are typically supported by state and/or municipal organizations; social cooperatives which adapte a multi-stakeholder governance model to connect to communities and improve welfare provision and, finally, social businesses which engage in entrepreneurial activities to adapted private sector business models and market-based strategies to go beyond Corporate Social Responsibility (CSR) (e.g, businesses which are related to renewable energy, see Bull et al., 2008 or Málovics et al., 2008), by running an enterprise that adopts a social mission. Particularly for this final category, Ridley-Duff (2008, p. 294) argues that even though social mission and social value creation are central for social enterprises, "there is an implicit assumption that profits are desirable so long as they can be channelled towards the collective needs of socially excluded groups".

Leaving aside definitional debates, another strong theme within the SE literature is that social entrepreneurs share much in common with traditional conceptualizations of entrepreneurship (Austin et al., 2006; Martin and Osberg, 2007; Shaw and Carter, 2007). Dees (2001) states that "(s)ocial entrepreneurs are one species in the genus entrepreneur. They are entrepreneurs with a social vision." Likewise, Grimes et al. (2013, p. 461) see social entrepreneurship as "the process of employing market-based methods to solve social problems." Considered alongside Defourny and Nyssens's (2016) typology of social enterprises, it seems appropriate to distinguish between different types of social enterprise. For our research, we are aligned most strongly with the entrepreneurial non-profits and the social business categories identified by Defourny and Nyssens's (2016) typology.

Building on these thoughts, we posit that research on EO may be helpful in developing an understanding of SEO, particularly a scale to measure a social enterprise's SEO. As several studies within the broader entrepreneurship research base have found a positive correlation between a higher degree of EO and the performance of firms (e.g., Wales et al., 2013), we believe it can be inferred that SEO, as a modification of EO, also influences the performance 
of social enterprises. Nevertheless, scientific work examining this is scarce with only a few authors having so far applied, slightly modified EO scales to the activities of social enterprises. For example, in their study of how the entrepreneurial processes represented by the EO construct might be different for social and commercial entrepreneurship Lumpkin et al. (2013) found that social enterprises differ from commercial enterprises in their social motivation/mission, opportunity identification, access to capital/funding, and engagement multiple stakeholders. With regard to firm performance, Miles et al. (2013) used the EO scale suggested by Covin and Slevin (1989) to measure the social value orientation of a social enterprise as a value-driven management philosophy, finding that social value orientation increases some levels of social performance. This was supported by the finding of by Coombes et al. 's (2011) examination of the influence of non-profit boards as strategic resources shaping the organization's EO and performance. Borrowing from Gouldner (1960), Hu and Pang (2013) identified proactiveness, innovativeness, and risk-taking as the main dimensions of EO in their empirical study on the relation between SEO and the performance of non-profit organizations. Their study found that the social entrepreneur's EO is an individual-level phenomenon, having a reciprocal relationship with their firm.

While this area of investigation is promising given its potential to advance both theory and practice concerning social enterprises, their activities and performance, the discussion presented indicates a lack of scales which can be used to measure SEO. We seek to address this gap by proposing an initial SEO scale based on input from experts in the entrepreneurship and social entrepreneurship scientific communities.

\section{Methodology}

\section{Delphi Study}

To identify appropriate measures for SEO, this investigation conducted a Delphi study among researchers who are experts in the fields of entrepreneurship and/or SE. Recent research by Ridley-Durr and Bull (2015) used a similar method when they sought the opinions of social enterprise scholars and post-graduate students on the nature and definition of SE. We sought to develop this by using the Delphi technic to collect qualitative data from a sample of scholarly experts in the fields of both entrepreneurship and social entrepreneurship. To ensure that a broad range of views toward SE were represented in the study, we sought to include participants from 
a wide sample of experts including members of the EMES research network for social enterprise, as well as scholars locates across Europe and the US who were not members of this network. In stage one of our study, our Delphi study was constructed as a series of two rounds of expert feedback aimed at generating constructs that combined aspects of social as well as entrepreneurial orientations. In stage 2 , to test the face validity of the newly created items to emerge from the Delphi study, we used a larger scale survey with 82 participants (cp. next chapter.) The Delphi method is a common and accepted exploratory research approach, used to establish a highly qualitative solution to a specific issue where no exact knowledge currently exists (Dalkey and Helmer, 1963; Landeta, 2006; Okoli and Pawlowski, 2004). Based on the rationale "two heads are better than one" (Dalkey et al., 1969), the Delphi method is a series of consecutive questionnaires where after each round of data collection the results of all questionnaires are provided to respondents (Schmidt, 1997; Brüggen and Willems, 2009). Participants may alter their opinion in each round until a general consensus has been achieved (Powell, 2003; Rowe et al., 2005). This study used the Delphi method because it holds distinctive advantages in comparison to other qualitative methods which seek to garner expert opinions. First, the approach is based on anonymity. In contrast, members of, for example, group discussions are in personal contact and some participants may dominate the discussion, leaving the statements of others unspoken and leading to distorted results. This bias is minimized with the Delphi method. Second, in group discussions, the participants have a fixed timetable regarding when the discussion will take place. Participants of the Delphi method, however, usually receive the questionnaire via email and consequently have a longer timeframe to answer its respective questions (Okoli and Pawlowski, 2004). Third, the Delphi method obtains a high degree of effectiveness in regard to the accuracy of judgments (Rowe and Wright, 2001) given that it allows for successive rounds of opinions to be sought and then clarifies. Participants are able to alter their opinion and may, for instance, adapt their views by having more time to review their previous answers and reflect on these. The Delphi method generally makes use of consensus instead of focusing on differences between opinions (Dalkey and Helmer, 1963), which is especially suitable for our research which sought to develop an SEO scale. In line with the research aims, obtaining opinions iteratively has the potential to lead to more robust results.

For the first round, there were several options for the approach to data collection, ranging from unstructured questionnaires to structured questionnaires based on extensive literature reviews 
(Hsu and Sandford, 2007). The questionnaire used in our study was generated based on a pretest conducted with ten international experts, comprising questions regarding the investigators' own definition(s) of EO and SE, i.e. the definitions developed by specific authors and used by the experts we approached. Additional questions aimed to obtain data regarding how the participants would measure the particular research orientation towards EO and SEO. The first Delphi round consisted of the following questions: 1) What is your definition of "EO", or which existing one do you use? 2) How would you measure "EO"? 3) What is your definition of "social entrepreneurship", or which existing one do you use? 4) How would you measure "social entrepreneurship orientation"?

Data was collected from 18 participants (out of 20 invitations, from ten EO and ten SE scholars) based in Europe and the United States. It was assumed that the number of participants was sufficient since it was substantially larger than the recommendation by Delbecq et al. (1975). As recommended, all respondents had a business school background and were contacted prior to implementation of the Delphi study (Okoli and Pawlowski, 2004). To prevent the influence of dominant individuals, answers given by the panels were anonymous (De Villiers et al., 2005; Keeney et al., 2006; von der Gracht, 2012). In order to foster feedback and consensus, a summary of the results from each round was provided, pointing out all answers from the participants as well as the number of experts supporting similar statements or views at the beginning of the second round. The participating experts were then asked to review and, if necessary, revise the summarized results.

\section{Expert Survey}

A key principle of scale development involves assessing the face validity of the derived items (e.g., Churchill, 1979). In other words, the items of a scale should be repeatedly presented to experts in order to rate their appropriateness for the given construct the items are intended to measure. Hardesty and Bearden, (2004) isolated two popular approaches of face validity testing. The first approach uses a Likert-type response format with categories of "very good", "good", "fair", or "poor" (Obermiller and Spangenberg, 1998) to rate the fit of each item with the underlying construct. Hence, an item that receives only very good ratings can be deemed face valid. A second approach instructs experts to assign the items to appropriate dimensions of that construct (e.g., Ohanian, 1990). Again, an item that is assigned to the dimension it should 
measure by all experts can be assumed to be face valid. This study followed the first approach for two reasons. First, as a result of the two Delphi study rounds, it is clear that experts are familiar with EO, making it safe to assume that applying the second method would make it much easier for the experts to assign the EO items to the subordinate EO dimensions, which would impede the assignment items representing socialness. In other words, the rating would be a function of familiarity instead of face validity. Second, the latter approach focuses on multiple dimensions, and the aim of this research is to identify a SEO scale, i.e. the best-fitting items for the overall construct, not its sub-dimensions. In line with a possible higher experts' familiarity with the EO dimensions, and similar to the argument presented previously, the experts were asked about the overall construct rather than their dimensions. For both reasons, the first approach of fit rating is applied. Overall, the survey sought to identify experts' perceived fit of the qualitatively derived items with the overall construct of SEO.

Having selected the method to assess face validity, our study continued with determining the sample and instrument used to obtain expert ratings, applying a systematic approach to finding relevant researchers to take part in the study. An initial literature search identified 152 papers from 323 scholars researching SE. Assuming that those authors may be considered experts, they were contacted to determine their interest in participating in the survey. For distribution reasons (the contacts are spread throughout the world), an online questionnaire consisting of an introduction, the definition of SEO, the fit rating of items, an option to provide comments about the items, and some relevant additional information (gender, age, research experience, institution, country) was deemed the most appropriate. The same 4-point Likert-type scale as suggested by Obermiller and Spangenberg (1998) was applied to assess the fit ( 1 = "very good", 2 = "good", 3 = "fair" and 4 = "poor"). Participation was completely voluntary and anonymous. No cash or non-cash incentives were provided. A total of 82 experts completed the survey, yielding a response rate of 25.4 percent. Table 1 provides descriptive information about the characteristics of the survey participants. 


\section{Results}

\section{First Delphi Round}

\section{Entrepreneurial orientation}

The first round showed very consistent results concerning the definition and measurement of EO. The main dimensions of EO identified by the participants were innovativeness (16 mentions out of 18), risk-taking (16), and proactiveness (13), followed by competitive aggressiveness and autonomy (5 each). These participants appeared to be reflecting the dimensions developed by Miller (1983) and advanced by Covin and Slevin (1989), Kemelgor (2002) and Lumpkin and Dess (1996). In accordance with Wiklund (1999), these are the dimensions which have been used most frequently in EO research.

Furthermore, a certain number of participants emphasized that EO is a "strategic posture" or a "strategic orientation" which a firm can make use of (4). A minority of participants based their definitions of EO on Drucker (1995) stating that a firm is entrepreneurially oriented when it seeks, identifies, recognizes, and evaluates an opportunity (3). The majority of participants however argued that they work with the EO dimensions of innovativeness, risk-taking, and proactiveness.

Concerning the measurement of EO, most of the participants suggested drawing from existing scales (12). In line with the above-mentioned dimensions of EO, eleven experts mainly referred to the scales developed by Covin and Slevin (1989), and five experts commented on work by Miller (1983). Among those 16 participants, three stated that either a combination of these two scales should be used, seven argued that the scales should be adopted as they are, and four said that they should be adapted to situational factors. One of the participants additionally proposed the dimensions of independence and competitive nature. In a broader sense, these dimensions can be considered as synonyms for autonomy and competitive aggressiveness, two dimensions that are included in the scale suggested by Lumpkin and Dess (1996). One respondent proposed measuring EO through items that intend to determine the level of importance of the respective dimensions in a firm. This may for instance be the item "actively seeking for entrepreneurial opportunities". 
In summary, the majority of the experts offered variations of the three-dimension EO scales suggested by Covin and Slevin (1989) and/or Miller (1983), which were known to all participants from both research fields.

\section{Social Entrepreneurship Orientation}

As discussed above, definitions of SE diverge in the literature. Given this it was unsurprising to find the same diversity of definitions emerging from the Delphi study. But even though SE "means different things to different people" (Dees, 2001), it was possible to investigate correspondence among the participants' answers. Since five out of 18 participants do not focus on research on SE and therefore did not answer the questions, 13 experts remained who provided answers concerning SEO.

The majority of the participants agreed that SE implies entrepreneurial behavior, and originates from entrepreneurship in a broader view, including managing existing organizations, as well as any type of entrepreneurial behavior such as opportunity recognition, innovative, pro-active, and risk-taking behavior (11). For example, one expert stated that SE is considered "any type of business activity which combines: acting entrepreneurial, [having] a social approach, and act[ing] profit-oriented."

Most of the participants pointed out that the main focus of SE lies in solving social problems, i.e. on the creation of social value (11). One expert saw SE as an "entrepreneurial endeavor, with the primary objective of creating social (instead of commercial) value." When focusing on the social mission, only five participants stated that this includes profit orientation. Two experts narrowed entrepreneurship to firms or businesses in this context.

Concerning the measurement of SEO, two participants emphasized that there is no adequate standardized inventory (yet) and stressed the need for it. One stated that this has to be developed carefully. A number of experts proposed making use of an existing scale and adapting it to SE (9). Based on this, several suggestions about how to connect EO with SE were made.

With regard to a modification approach, participants recommended adapting the scales developed by Covin and Slevin (1989) and Miller (1983). Each scale was proposed by three 
participants and the remaining three also suggested adapting an existing scale, although they did not specify which one. Three participants proposed the inclusion of an additional dimension having the social component which can be named the degree of socialness. For this dimension, the following indicators were proposed: a) the extent to which an entrepreneur (or his/her business) focuses on creating social value, b) the degree to which value creation guides a firm's strategy, c) the focus on entrepreneurial solutions for social problems, and d) the motivation to lay the focus not only on financial profits, but on social added value as well. These indicators can be considered as a suitable approach for measuring the socialness of an individual or an organization. All suggestions were reviewed by the participants of the Delphi study within the second round, leading to a more concrete SEO scale.

\section{Second Delphi Round}

\section{Entrepreneurial Orientation}

The results of the second Delphi round largely confirmed the first round's answers concerning the definition and measurement or EO and also showed improved consensus among participants. Although the dimensions of innovativeness, risk-taking, and proactiveness are most frequently used to measure EO (Wales et al., 2013), the dimensions of competitive aggressiveness and autonomy were also mentioned in round one and could be taken into consideration. This is why a question was added that was directed towards this topic, asking whether the experts would vote to in- or exclude these dimensions. Sixteen (out of 18) respondents expressed that EO should mainly consist of the dimensions risk-taking and innovativeness, while 13 respondents also agreed on proactiveness as an additional dimension. Four suggested including competitive aggressiveness and three experts explicitly stated that they saw no use for including this dimension. In practice few empirical studies have investigated competitive aggressiveness as a dimension of EO. The majority of empirical studies on EO do not utilize this dimension (Wales et al., 2013). The main reason for this is that competitive aggressiveness is usually embedded in the dimension of proactiveness and consequently does not need to be measured separately (e.g., Covin and Slevin, 1989). One participant in the second round of the Delphi study noted that SE usually do not intend to compete with other SEs; this participant instead would like to see cooperation with "actors some would consider as their rivals." An underlying reason here might be that the social issues can often be addressed more effectively through collaboration, achieving the social mission more quickly as a result. This hypothesis is in line with Lumpkin et al. (2013) who state that 
competitive aggressiveness limits collaboration and makes the creation of social value inefficient. In turn, the dimension of competitive aggressiveness may distract attention from creating social value in an efficient way, even though some authors state that SE also operates in a competitive context because it needs to compete for workforces or philanthropic grants (e.g., Dees et al., 2002; Light, 2008). Moreover, it is important to achieve a balance between collaboration and competition (Kickul and Bacq, 2012). As competitive aggressiveness as a dimension of EO has rarely been empirically investigated (Crucke and Decramer, 2016; Hu and Pang, 2013) and, that a reasonable number of participants in the Delphi study did not support this dimension, it was excluded from the suggested scale. Since only one expert advocated including autonomy, and four explicitly argued against it, too was not considered a relevant dimension for inclusion.

\section{Social Entrepreneurship Orientation}

With regard to the measurement of SEO, most participants proposed making use of existing scales and adapting them to the particular circumstances if necessary. The 13 participants also did not see a need to make changes to the proposed definitions of SE. However, concerning SE, a few respondents did suggest altering the entire concept (3). In particular, one respondent stated that the financial side of SE must not be neglected otherwise, there is a risk that only socialness is measured and that the sustainability of the undertaking is not examined. After all, a financially stable organization may obtain more legitimacy as well as persuasiveness. Three respondents suggested utilizing the additional dimension 'socialness' which we consider in more detail below.

Two participants emphasized that the combination or adoption of existing scales should be conducted carefully. Otherwise the possibility exists that EO in SE is measured without also considering the social component of SE. Table 2 provides an overview of the suggested items for the three selected dimensions.

--- Insert Table 2 about here --- 
The results presented so far are largely based on the views of the majority of participants. This excludes useful insights provided by individual experts. In order to further elaborate the scale derived from the Delphi results, the following section draws on the previous suggestions while also considering other respondents' statements in the context of the existing literature.

\section{Development of a SEO Scale Based on Delphi Results}

Two respondents recommended altering the first item of the innovativeness dimension; these experts stated that continuous renewal and social innovation "are not necessarily the same." This suggestion was accepted by removing the term "continuous renewal" because it implies incremental innovations instead of radical ones. Social innovations are after all rather transformative in nature (Didero et al., 2008). Based on another suggestion stressing the similar adoption character of innovativeness, indicators two and four were combined. The third indicator was adapted by substituting the expression "all the time" with "very frequently." One researcher offered a general criticism that " $[\mathrm{t}]$ hese items assume the firm has a social mission and so is directly relevant to a social enterprise not a firm say involved in aspects of SE." However, because this scale intends to be applicable for organizations which incorporate a social mission at least to some degree in their overall objective, this feedback was not addressed.

One respondent expressed that the third item related to risk-taking was phrased in reversed terms, arguing that those items are often misunderstood by respondents when completing questionnaires. With this in mind, avoiding unexpected influences on the factor structure (Hughes, 2009) as a result of this misunderstanding is more important than the possible benefits of keeping the reverse coded item (e.g., acquiescence, Baumgartner and Steenkamp, 2001). This is why the indicator was rephrased to "We avoid the cautious line of action if social opportunities might be lost that way." The second item, risk-taking, was criticized by one expert as being phrased in terms that were too generic, while another expert noted that the connection to SE was missing. Consequently, the item was altered to "Our organization has a strong tendency to be ahead of others in addressing its social mission."

An important factor related to SE is replication, which can be referred to in the context of proactiveness where certain SEs are the first to initiate actions which are subsequently copied by other SEs or social enterprises. This is supported by recent research (Halberstadt and Kraus, 
2016) which has found that copying social entrepreneurial ideas can sometimes lead to commercial businesses. Moreover, a modified version of this item has been utilized as part of a social value orientation scale proposed by Miles et al. (2014). Concerning socialness, no consensus was achieved in the second Delphi round, so the different participants' suggestions were collected and drawn back to the literature. Consequently, as a result of the Delphi study, the following SEO scales were developed, consisting of the three dimensions of (social) innovativeness, risk-taking, and proactiveness, as well as the additional dimension of socialness, with the new items phrased in the following manner (see Table 3).

--- Insert Table 3 about here ---

\section{Expert Survey}

The detail provided by the 82 expert ratings reveals a very clear consensus. None of the items was found to be absolutely inappropriate - even the weakest scoring item (socialness 3) was a very good fit for 12.2 percent or ten raters. In other words, the two Delphi studies identified reasonable items for measurement of SEO. However, deciding which item should be omitted from the scale is a subjective question, so the study applied three principles derived from the literature. First, an item was removed if less than two-thirds (66 percent) of the experts perceived it as a very good or good fit for measuring SEO. Second, an item was removed if it yielded an absolute low sum score (Hardesty and Bearden, 2004) - a weighted index of the absolute frequency of the scale points "very good" ( 3 points), "good" ( 2 points), and "fair" (1 point). Third, the item was removed if it did not differ substantially from the scale's midpoint (theoretical mean of a 4-point scale $=2.5$ ). This study conducted Welch's t-tests against this mean to implement this principle. The first two principles differ in their assumption of whether a "fair fit" should be seen as below (first principle) or above (second principle) a minimum level of fit. The third principle adds an inferential perspective to the descriptive perspectives applied above. For the purposes of decision making, the principles were not concatenated, i.e. an item can be deemed as "face valid" even if it does not fulfill one of the three principles. It should also be noted that the third principle (t-test) is influenced by the relatively large number of experts for a face validity check. 
As depicted in Table 4, implementing these three principles resulted in the deletion of three items. The item Socialness 3 was perceived as a good-fitting indicator by only 50.0 percent (41) of the experts, achieved the lowest score (also rewarding a fair fit, sum score $=128$ ), and was not found to be significantly different from the theoretical mean $(\mathrm{M}=2.56$ to 2.5 ; $\mathrm{t}$-value $=.60$; $\mathrm{p}=.55)$. Socialness 5 was also removed since it yielded only 63.4 percent acceptance, the second-lowest score $($ sum score $=168)$. Despite significance $(t-v a l u e=-3.09, p=.00)$, the low difference to the theoretical mean $(\mathrm{M}=2.20$ to 2.5$)$ suggested a removal as well. A theoretical perspective (described below) further elaborates this decision. Based on a similar pattern of results, the item Socialness 6 was removed - due to its weak acceptance (59.8 percent), low score (175), and theoretical considerations - in spite of the significant difference to the scale mean $(\mathrm{t}$-value $=-3.13 ; \mathrm{p}=.00)$.

The analysis verified what can also be explained theoretically. Concerning Socialness 3, the experts in the Delphi study proposed integrating general sustainability because it can be argued that all social entrepreneurial activity aims to contribute to sustainability. However, the suggested item, even if adapted from an existing scale, only measures one aspect of sustainability: the ecological perspective. This might be a good fit for green or eco entrepreneurship. This issue was also present for Socialness 5 since the item focused on a specific form of SE which does not fit into a broader approach to measuring SEO. And, if the main focus of the social entrepreneurial activity is not on disadvantaged people, the item does not even measure a specific form of SE, but only whether the business is managed in a (socially) sustainable way. Socialness 6 did not address the core business model or activity, but only the management of a (social) business instead. This item also measured corporate volunteering as a form of corporate social responsibility (Perrini et al., 2007; Grant, 2012) and thus also had to be excluded., The relatively poor fit with the overall SEO scales as perceived by the experts is a likely result of these issues. The final items can be found in Table 5. 


\section{Discussion}

As a result of the mixed-method approach including 18 experts from the two-staged Delphi study and 82 experts from an online survey, 12 items measuring four dimensions of SEO are proposed. In sum, the experts contributed to the development of a measure based on existing EO scales that were applied to the specific construct of SE. Even though this may not be an unexpected finding, these observations do make an important and relevant contribution to the measurement of SE. This is the only measure based on a broad empirical study and experts' assessments. It further shows that the most complex construct within the combined area of "social" and "entrepreneurship", and thus causing the variety of SE definitions, seems to be the entrepreneurial component. This explains the focus on the three main dimensions of EO, innovativeness, risk-taking and proactiveness - all then adjusted to the social mission os social enterprise.

Considering the "social" in SEO, it can be stated that the social mission itself seems to be less multifaceted. In line with the literature, the experts agreed on SE mainly intending to solve social challenges and/or following a social mission using entrepreneurial approaches. Since social entrepreneurs follow strong entrepreneurial approaches, it raises questions about the relationship between the dual missions of social and financial goals. The experts' view of developed scales could be interpreted in a way that, for social entrepreneurs at least, makes both strategic orientations and missions inseparable. Therefore (and despite its obviousness), the most appropriate way to derive a SEO scale is to integrate this social mission focus into the selected EO scales. The magnitude of socialness possessed by the firm is then added to this core construct by three additional items.

Like the inseparability of missions, it is argued that for social entrepreneurs, who are running for-profit businesses, social and financial value creation are inseparable. In such businesses, long term financial performance cannot be achieved without social value creation and vice versa. From a practical point of view, the developed SEO scale helps to understand social EO more deeply - especially among several stakeholders who are crucial for social entrepreneurs (e.g. beneficiaries of created social value, public sector actors, or impact investors). From a research perspective, the SEO scale provides for a deeper analysis of the relationship between 
(social) EO and the performance of social enterprise (which consists of inseparable value components).

Existing SE literature has strongly focused on discussing the definitions of social enterprises. With this in mind, the definition itself is not unambiguous. As the SEO scale developed here will help to identify organizations' social entrepreneurial characteristics, it also helps to better categorize organizations as social enterprises, mainstream enterprises, or as enterprises somewhere in between. We argue that the scale we have developed can help identify which enterprises are categorized as social business and as entrepreneurial non-profits (Defourny and Nyssens, 2016) as well as provide a tool for enterprises to measure their social entrepreneurial orientation at the organizational level. The reason why our newly developed scale will be useful for investigating especially social businesses and entrepreneurial non-profits on the basis that these are most likely to have been started by individuals with an EO. In the future, sustainability and social value creation will become increasingly important for organizations of all sizes, types and purposes. Our SEO scale could be tested and validated in several types of organizations including public sector organizations and social co-operatives (Defourny and Nyssens, 2016), in a manner that is complementary to the application and testing of the EO scale in a wide variety of organizations (see Morris et al., 2011; Miles et al., 2013). This in turn means that more tools will be needed for the evaluation of how deeply organizations have integrated sustainability and social value creation targets into their strategies.

The SEO scale proposed will enable future research to empirically investigate what, to date, have been posited as conceptual or theoretical relationships. Lepoutre et al. (2013) proposed three selection criteria for SE that stand out from previous literature: 1) the predominance of a social mission, 2) the importance of innovation, and 3) the role of earned income. Since innovation is seen as a main criterion for entrepreneurship and is thus considered in EO as well as SEO, the scales here will allow a comparison of the degree of innovativeness simultaneously and in both directions.

The purpose of this study was to provide a set of items measuring SEO. The existing EO literature has increased the knowledge of how entrepreneurial actions are tied to outcomes, even though this research stream has not yet been widely adapted to the differences in the form of 
entrepreneurship across contexts and business models (Morris et al., 2011). The scale developed here has the potential to make a substantial contribution as an effective research tool. Lumpkin et al. (2013) elaborate on EO in social contexts, and this study contributes to EO research by providing a measurement tool for hybrid organizations which are simultaneously business and social mission-oriented. The new scale makes it possible to study the empirical feasibility of applying the EO construct in a SE context. It also contributes to the further development of the SE literature by linking back to the original field of entrepreneurship (Nicolopoulou, 2014).

In terms of implications for management, this study provides a tool for demonstrating the complexity of social enterprises. The approach to the measurement of SEO considers not only the development of new products and services, but the means through which the enterprises can pursue social mission-related and commercial opportunities as well. This study also has implications for policymakers and other stakeholders. The SEO scale provides a tool for policymakers to better differentiate between different types of organizations which, in turn, will help them to provide more target group-oriented support. Social impact investors seek funding targets which simultaneously produce economic growth and employment while creating social value in general. For investors, this study provides a new means to measure the motivations of different types of enterprises. By clarifying and distinguishing the underlying dimensions of a social entrepreneur, this scale provides a pathway for studying how different dimensions are related to both the social and economic performance of the firm.

As with all studies, the work here has its limitations. The Delphi panelists were mainly from the United States and Europe, so panelists from other continents would help achieve a broader global perspective. The other limitation of our study is that this SEO scale might not be relevant to all kinds of social enterprises. Using the developed items as a foundation, more research can lead to an approach matching the criteria of less entrepreneurial social enterprises like public sector social enterprises and social co-operatives because of their collective and emergent nature (Defourny and Nyssens, 2016). Additionally, future research should examine how well the developed scale fits studies of different types of social enterprises throughout the world. 


\section{Conclusions}

Apart from being the first to derive an SEO scale on an empirical basis, this study delivers several other important contributions. The removal of the three items addressing socialness ${ }^{1}$ demonstrates two important findings referring to the (mis)understanding of SE and SEO as a result.

First, Socialness 3 targets the reduction of $\mathrm{CO}_{2}$ emissions and waste. Both are areas of ecological improvement/solving ecological problems (see Scott-Cato et al., 2008). Different arguments can be presented regarding how this does not address social, but ecological or green entrepreneurship instead - which falls under the umbrella of sustainability or sustainable entrepreneurship (Fellnhofer et al., 2014); it's social, but just not SE in and of itself (Hockerts and Wüstenhagen, 2010, Zahra et al., 2009). Following this argumentation, this item would measure ecological entrepreneurship orientation as a separate or additional form of EO. Nevertheless, it can be also argued that both fields are not parallel but interconnected streams because 1) every ecological issue has an impact on societal problems and vice versa, or 2) all environmental problems are simultaneously social issues. But even following this line of thinking, this item does not necessarily match the criteria of socialness in general. In fact, it instead indicates a specific form of SE. And evidently, social entrepreneurial activity arises in a variety of fields. So as a result, this does not measure the general SEO, but emphasizes a certain aspect instead. This reasoning also applies to the item Socialness 5.

Second, both items Socialness 5 and Socialness 6 illustrate the uncertainty and blurred margins of/to/with CSR and its related phenomena. Put simply, even experts in the field of SE were not able to reliably distinguish between social entrepreneurial and social responsibility issues. When addressing "socialness", we should distinguish between the social mission (addressing a social issue as a core activity) and managing a (social, green, or commercial) business in a social way. Further research will have to address the differentiation and distinctiveness of these aspects. It's doubtful that non-experts such as entrepreneurs, investors, managers, or even students operating as respondents in entrepreneurship research will be able to fully understand and correctly distinguish them.

\footnotetext{
${ }^{1}$ Socialness 3: We measure CO2 emissions and/or our generated waste and actively try to reduce it; Socialness 5: We actively employ socially disadvantaged people [e.g. disabled people, immigrants, elderly people]; Socialness 6: We support and encourage our employees to get active in voluntary commitments outside of our organization in order to address social issues.
} 
Notwithstanding the promising results regarding content and expert input through a careful sequence of Delphi and survey methods, future research is challenged to quantitatively validate the proposed final scale in the context of firms with different levels of degree of the socialness dimension, to evaluate the statistical reliability and validity properties. We are convinced that that the SEO construct will be useful for investigating social businesses and/or entrepreneurial non-profits which are most likely to have been started by individuals with an EO. However, other approaches - such as public sector social enterprises or social cooperatives (cp. Defourny and Nyssens, 2016) - might also need alternative SEO research instruments to investigate them effectively because of their collective and more emergent nature.

\section{References}

Alvord, S.H., Brown, L.D. and Letts, C.W. (2004), "Social entrepreneurship and societal transformation an exploratory study", The journal of applied behavioral science, Vol. 40 No. 3, pp.260-282.

Austin, J., Stevenson, H. and Wei- Skillern, J. (2006), "Social and commercial entrepreneurship: same, different, or both?", Entrepreneurship Theory and Practice, Vol. 30 No. 1, pp.1-22.

Bacq, S. and Janssen, F. (2011), "The multiple faces of social entrepreneurship: A review of definitional issues based on geographical and thematic criteria", Entrepreneurship \& Regional Development, Vol. 23 No. 5-6, pp.373-403.

Baumgartner, H. and Steenkamp, J.-B.E.M. (2001), "Response styles in marketing research: A cross-national investigation", Journal of Marketing Research, Vol. 38 No. 2, pp.143-156.

Bouncken, R.B., Plüschke, B.D., Pesch, R. and Kraus, S. (2016), "Entrepreneurial orientation in vertical alliances: joint product innovation and learning from allies", Review of Managerial Science, Vol. 10 No. 2, pp.381-409.

Brockhoff, K. (1975), "The performance of forecasting groups in computer dialogue and face to face discussions", in Linstone, M. and Turoff, M. Eds.), The Delphi method: Techniques and applications. Addison-Wesley, London.

Brouard, F. and Larivet, S. (2009) Social Entrepreneurship: definitions and boundaries. Paper presented at ANSER-ARES 2009 Conference Association for Non-profit and Social Economy Research/Association de recherche des organismes sans but lucratif et de l'économie sociale, Ottawa, Ontario. 
Brüggen, E. and Willems, P. (2009), "A critical comparison of offline focus groups, online focus groups and e-Delphi", International Journal of Market Research, Vol. 51 No. 3, pp.363-381.

Choi, N. and Majumdar, S. (2014), "Social entrepreneurship as an essentially contested concept: Opening a new avenue for systematic future research", Journal of Business Venturing, Vol. 29 No. 3, pp.363-376.

Churchill, G.A. (1979), "A Paradigm for Developing Better Measures of Marketing Constructs", Journal of Marketing Research, Vol. 16 No. 1, pp.64-73.

Coombes, S.M., Morris, M.H., Allen, J.A. and Webb, J.W. (2011), "Behavioural Orientations of Non- Profit Boards as a Factor in Entrepreneurial Performance: Does Governance Matter?", Journal of Management Studies, Vol. 48 No. 4, pp.829-856.

Covin, G.J. and Miller, D. (2013), "International Entrepreneurial Orientation: Conceptual Considerations, Research Themes, Measurement Issues, and Future Research Directions", Entrepreneurship: Theory \& Practice, Vol. 38 No. 1, pp.11-44.

Covin, J. and Slevin, D. (1989), "Strategic management of small firms in hostile and benign environments", Strategic Management Journal, Vol. 10 No. 11, pp.75-87.

Covin, J.G., Green, K.M. and Slevin, D.P. (2006), "Strategic process effects on the entrepreneurial orientation-sales growth rate relationship", Entrepreneurship: Theory \& Practice, Vol. 30 No. 1, pp.57-81.

Covin, J.G. and Wales, W.J. (2012), "The measurement of entrepreneurial orientation", Entrepreneurship Theory and Practice, Vol. 36 No. 4, pp.677-702.

Crucke, S. and Decramer, A. (2016), "The Development of a Measurement Instrument for the Organizational Performance of Social Enterprises", Sustainability, Vol. 8 No. 2, pp.161.

Dacin, P.A., Dacin, M.T. and Matear, M. (2010), "Social entrepreneurship: Why we don't need a new theory and how we move forward from here", The Academy of Management Perspectives, Vol. 24 No. 3, pp.37-57.

Dalkey, N.C., Brown, B.B. and Cochran, S. (1969) The Delphi method: An experimental study of group opinion, Rand Corporation Santa Monica, CA.

Dalkey, N.C. and Helmer, O. (1963), "An experimental application of the Delphi method to the use of experts", Management science, Vol. 9 No. 3, pp.458-467.

Danko, A., Brunner, C. and Kraus, S. (2011), "Social Entrepreneurship - An Overview of the Current State of Research", European Journal of Management, Vol. 11 No. 1, pp.82-90.

De Villiers, M.R., De Villiers, P.J. and Kent, A.P. (2005), "The Delphi technique in health sciences education research", Medical teacher, Vol. 27 No. 7, pp.639-643. 
Dees, J.G. (2001) The Meaning of Social Entrepreneurship. Durham, NC: Duke University.

Dees, J.G. (2007), "Taking social entrepreneurship seriously", Society, Vol. 44 No. 3, pp.2431.

Dees, J.G., Emerson, J. and Economy, P. (2002) Strategic tools for social entrepreneurs: Enhancing the performance of your enterprising nonprofit, John Wiley \& Sons.

Defourny, J. and Nyssens, M. (2016) Fundamentals for an International Typology of Social Enterprise Models, ICSEM Working Papers, No. 33, ICSEM, Liege.

Delbecq, A.L., Van de Ven, A.H. and Gustafson, D.H. (1975) Group techniques for program planning: A guide to nominal group and Delphi processes, Scott, Foresman, Glenview, IL.

Dey, P. and Steyaert, C. (2012), "Social entrepreneurship: Critique and the radical enactment of the social", Social Enterprise Journal, Vol. 8 No. 2, pp.90-107.

Didero, M., Gareis, K., Marques, P. and Ratzke, M. (2008), "Differences in innovation culture across Europe", Transform, dissussion paper, Vol. No. 022780.

Doherty, B., Thompson, J. and Spear, R. (2006), "Social entrepreneurship: a different model?", International journal of social economics, Vol. 33 No. 5/6, pp.399-410.

Drayton, W. (2002), "The citizen sector: Becoming as entrepreneurial and competitive as business", California Management Review, Vol. 44 No. 3, pp.120-132.

Drucker, P. (1995) Innovation \& Entrepreneurship, Harper Business, New York.

Emerson, J. (2003), "The blended value proposition: Integrating social and financial returns", California management review, Vol. 45 No. 4, pp.35-51.

Fellnhofer, K., Kraus, S. and Bouncken, R. (2014), "Sustainable Entrepreneurship: A Current Review of Literature", International Journal of Business Research, Vol. 14 No. 3, pp.163172.

Gouldner, A.W. (1960), "The norm of reciprocity: A preliminary statement", American sociological review, Vol. No., pp.161-178.

Grant, A.M. (2012), "Giving time, time after time: Work design and sustained employee participation in corporate volunteering", Academy of Management Review, Vol. 37 No. 4, pp.589-615.

Grimes, M.G., McMullen, J.S., Vogus, T.J. and Miller, T.L. (2013), "Studying the origins of social entrepreneurship: compassion and the role of embedded agency", Academy of management review, Vol. 38 No. 3, pp.460-463.

Halberstadt, J. and Kraus, S. (2016), "Social entrepreneurship: the foundation of tomorrow's commercial business models?", International Journal of Entrepreneurial Venturing, Vol. 8 No. 3, pp.261-279. 
Hardesty, D.M. and Bearden, W.O. (2004), "The use of expert judges in scale development: Implications for improving face validity of measures of unobservable constructs", Journal of Business Research, Vol. 57 No. 2, pp.98-107.

Hockerts, K. and Wüstenhagen, R. (2010), "Greening Goliaths versus emerging Davids Theorizing about the role of incumbents and new entrants in sustainable entrepreneurship", Journal of Business Venturing, Vol. 25 No. 5, pp.481-492.

Hsu, C.-C. and Sandford, B.A. (2007), "The Delphi technique: making sense of consensus", Practical assessment, research \& evaluation, Vol. 12 No. 10, pp.1-8.

$\mathrm{Hu}, \mathrm{Y}$. and Pang, X. (2013), "Social Entrepreneurial Orientation and Performance of Nonprofit Organizations: An Empirical Study in China", Journal of Applied Sciences, Vol. 13 No. 19, pp.3989.

Hughes, G.D. (2009), "The Impact of Incorrect Responses to Reverse-Coded Survey Items", Research in the Schools, Vol. 16 No. 2.

Hughes, M., Eggers, F., Kraus, S. and Hughes, P. (2015), "The Relevance of Slack Resource Availability and Networking Effectiveness for Entrepreneurial Orientation", International Journal of Entrepreneurship and Small Business, Vol. 16 No. 1, pp.116-138.

Hughes, M. and Morgan, R.E. (2007), "Deconstructing the relationship between entrepreneurial orientation and business performance at the embryonic stage of firm growth", Industrial Marketing Management, Vol. 36 No. 5, pp.651-661.

Kanter, R. and Purrington, C. (1998), Lockheed Martin IMS: Making a ontribution and a Profit, Harvard Business School case, 399-018.

Keeney, S., Hasson, F. and McKenna, H. (2006), "Consulting the oracle: ten lessons from using the Delphi technique in nursing research", Journal of advanced nursing, Vol. 53 No. 2 , pp.205-212.

Kickul, J.R. and Bacq, S. (2012) Patterns in social entrepreneurship research, Edward Elgar Publishing.

Kraus, S., Filser, M., O’Dwyer, M. and Shaw, E. (2013), "Social Entrepreneurship: An exploratory citation analysis", Review of Managerial Science, Vol. No., pp.1-18.

Krugman, P. (2009), The Conscience of a Liberal: Reclaiming America from the Right. London: Penguin.

Krugman, p. (2013), End this Depression Now!, New York: W.W. Norton \& Co.

Landeta, J. (2006), "Current validity of the Delphi method in social sciences", Technological forecasting and social change, Vol. 73 No. 5, pp.467-482.

Leadbeater, C. (1997) The rise of the social entrepreneur, Demos. 
Lepoutre, J., Justo, R., Terjesen, S. and Bosma, N. (2013), "Designing a global standardized methodology for measuring social entrepreneurship activity: the Global Entrepreneurship Monitor social entrepreneurship study", Small Business Economics, Vol. 40 No. 3, pp.693714.

Light, P.C. (2008) The search for social entrepreneurship, Brookings Institution Press.

Lumpkin, G.T. and Dess, G.G. (1996), "Clarifying the entrepreneurial orientation construct and linking it to performance", Academy of Management Review, Vol. 21 No. 1, pp.135-172.

Lumpkin, G.T., Moss, T.W., Gras, D.M., Kato, S. and Amezcua, A.S. (2013), "Entrepreneurial processes in social contexts: how are they different, if at all?", Small Business Economics, Vol. 40 No. 3, pp.761-783.

Málovics, G., Csigene, N. and Kraus, S. (2008), "The Role of Corporate Social Responsibility in Strong Sustainability", Journal of Socio-Economics, Vol. 37 No. 3, pp.907-918.

Martin, R.L. and Osberg, S. (2007), "Social entrepreneurship: The case for definition", Stanford social innovation review, Vol. 5 No. 2, pp.28-39.

Miles, M.P., Verreynne, M.-L. and Luke, B. (2014), "Social enterprises and the performance advantages of a Vincentian marketing orientation", Journal of business ethics, Vol. 123 No. 4, pp.549-556.

Miles, M.P., Verreynne, M.-L., Luke, B., Eversole, R. and Barraket, J. (2013), "The relationship of entrepreneurial orientation, Vincentian values and economic and social performance in social enterprise", Review of Business, Vol. 33 No. 2, pp.91-102.

Miller, D. (1983), "The correlates of entrepreneurship in three types of firms", Management Science, Vol. 29 No. 7, pp.770-791.

Miller, D. (2011), "Mller (1983) Revisited: A reflction and Some Suggestions for the Future”, Entrepreneurship Theory and Practice,Vol. 35 No. 5, pp.873-894.

Morris, M.H., Webb, J.W. and Franklin, R.J. (2011), "Understanding the manifestation of entrepreneurial orientation in the nonprofit context", Entrepreneurship Theory and Practice, Vol. 35 No. 5, pp.947-971.

Nicholls, A. (2010), "The legitimacy of social entrepreneurship: reflexive isomorphism in a pre-paradigmatic field", Entrepreneurship Theory and Practice, Vol. 34 No. 4, pp.611-633.

Nicolopoulou, K. (2014), "Social entrepreneurship between cross- currents: toward a framework for theoretical restructuring of the field", Journal of Small Business Management, Vol. 52 No. 4, pp.678-702.

Obermiller, C. and Spangenberg, E.R. (1998), "Development of a scale to measure consumer skepticism toward advertising", Journal of consumer psychology, Vol. 7 No. 2, pp.159-186. 
Ohanian, R. (1990), "Construction and validation of a scale to measure celebrity endorsers' perceived expertise, trustworthiness, and attractiveness", Journal of advertising, Vol. 19 No. 3, pp.39-52.

Okoli, C. and Pawlowski, S.D. (2004), "The Delphi method as a research tool: an example, design considerations and applications", Information \& management, Vol. 42 No. 1, pp.1529.

Peredo, A.M. and McLean, M. (2006), "Social entrepreneurship: A critical review of the concept", Journal of World Business, Vol. 41 No. 1, pp.56-65.

Perrini, F., Russo, A. and Tencati, A. (2007), "CSR strategies of SMEs and large firms. Evidence from Italy", Journal of business ethics, Vol. 74 No. 3, pp.285-300.

Powell, C. (2003), "The Delphi technique: myths and realities", Journal of advanced nursing, Vol. 41 No. 4, pp.376-382.

Ridley-Duff, R. (2008) 'Social enterprise as a socially rational business', International Journal of Entrepreneurial Behaviour and Research, 14(5): 291-312.

Ridley-Duff, R. and Bull, M. (2015) (2 ${ }^{\text {nd }}$ Edition), Understanding social enterprise: Theory and practice, Sage, London.

Rigtering, C., Kraus, S., Eggers, F. and Jensen, S.H. (2014), "A comparative analysis of the entrepreneurial orientation/growth relationship in service firms and manufacturing firms", Service Industries Journal, Vol. 34 No. 4, pp.275-294.

Rowe, G. and Wright, G. (2001), "Expert opinions in forecasting: the role of the Delphi technique", Principles of forecasting. Springer.

Rowe, G., Wright, G. and McColl, A. (2005), "Judgment change during Delphi-like procedures: The role of majority influence, expertise, and confidence", Technological Forecasting and Social Change, Vol. 72 No. 4, pp.377-399.

Schaltegger, S. and Wagner, M. (2011), "Sustainable entrepreneurship and sustainability innovation: categories and interactions", Business Strategy and the Environment, Vol. 20 No. 4, pp.222-237.

Schmidt, R.C. (1997), "Managing Delphi surveys using nonparametric statistical techniques*", Decision Sciences, Vol. 28 No. 3, pp.763-774.

Semrau, T., Ambos, T.C. and Kraus, S. (2016), "Entrepreneurial orientation and SME performance across societal cultures", Journal of Business Research, Vol. 69 No. 5, pp.19281932.

Shaw, E and Carter, S., (207), "Social entrepreneurship: Theretical antecedents and empirical analysis of entrepreneurial proesses and outcoms", Journal of Small Business and Enterprise Development, 14(3), pp 418-434 
Shaw, E. and de Bruin, A. (2013), "Recnsidering capitalisn: the promise of social innovation and social entrepreneurship?", International Small Business Journal, 31(7): 737-746

Shaw, E., Gordon, J., Harvey, C and Maclean, M. (2013), "Exploring comtemporary entrepreneurial philanthropy", International Small Business Journal, 31:5, pp. 580-599.

Sheehan, J.J. (2009), "Biofuels and the conundrum of sustainability", Current Opinion in Biotechnology, Vol. 20 No. 3, pp.318-324.

Short, J.C., Moss, T.W. and Lumpkin, G.T. (2009), "Research in social entrepreneurship: Past contributions and future opportunities", Strategic Entrepreneurship Journal, Vol. 3 No. 2, pp.161-194.

Teasdale, S. (2011), “What's in a Name? Making Sense of Social Enterprise Discourses”, Public Policy and Administration, 27(2):99-119

Thompson, J.L. (2002), "The world of the social entrepreneur", International journal of public sector management, Vol. 15 No. 5, pp.412-431.

Vega, G. and Kidwell, R.E. (2007), "Toward a typology of new venture creators: Similarities and contrasts between business and social entrepreneurs", New England Journal of Entrepreneurship, Vol. 10 No. 2, pp.15.

von der Gracht, H.A. (2012), "Consensus measurement in Delphi studies: Review and implications for future quality assurance", Technological Forecasting and Social Change, Vol. 79 No. 8, pp.1525-1536.

Wales, W.J., Gupta, V.K. and Mousa, F.-T. (2013), "Empirical research on entrepreneurial orientation: An assessment and suggestions for future research", International Small Business Journal, Vol. 31 No. 4, pp.357-383.

Weerawardena, J. and Mort, G.S. (2006), "Investigating social entrepreneurship: A multidimensional model", Journal of world business, Vol. 41 No. 1, pp.21-35.

Wiklund, J. (1999), "The sustainability of the entrepreneurial orientation-performance relationship", Entrepreneurship Theory and Practice, Vol. 24 No. 1, pp.37-48.

Zahra, S.A., Gedajlovic, E., Neubaum, D.O. and Shulman, J.M. (2009), "A typology of social entrepreneurs: Motives, search processes and ethical challenges", Journal of business venturing, Vol. 24 No. 5, pp.519-532.

Zahra, S.A., Newey, L.R. and Li, Y. (2014), "On the frontiers: The implications of social entrepreneurship for international entrepreneurship", Entrepreneurship Theory and Practice, Vol. 38 No. 1, pp.137-158. 
Tables

\begin{tabular}{|c|c|c|c|}
\hline Variable & Frequencies & Variable & Frequencies \\
\hline Gender & $\begin{array}{ll}\text { - } & \text { Male: } 33 \\
\text { - } & \text { Female: } 49\end{array}$ & \multirow[t]{3}{*}{ Country } & \multirow{3}{*}{$\begin{array}{ll}\text { - } & \text { Austria: } 6 \\
\text { - } & \text { France: } 6 \\
\text { - } & \text { Germany: } 9 \\
\text { - } & \text { Switzerland/Liechtenstein: } 14 \\
\text { - } & \text { Portugal: } 3 \\
\text { - } & \text { Spain: } 3 \\
\text { - } & \text { The Netherlands: } 3 \\
\text { - } & \text { UK: } 4 \\
\text { - } & \text { US: } 10 \\
& \\
\text { (single cases omitted) }\end{array}$} \\
\hline Experience & $\begin{array}{ll}\text { - } & \text { Less than } 3 \text { years: } 11 \\
\text { - } & 3-5 \text { years: } 14 \\
\text { - } & \text { 5-10 years: } 27 \\
\text { - } & 11-20 \text { years: } 17 \\
\text { - } & \text { More than } 20 \text { years: } 13 \\
\end{array}$ & & \\
\hline Institution & $\begin{array}{ll}\text { - } & \text { Collegiate university (publicly funded): } 57 \\
\text { - } & \text { Private university (privately funded): } 12 \\
\text { - } & \text { Federal college (publicly funded): } 7 \\
\text { - } & \text { Private college (privately funded): } 4\end{array}$ & & \\
\hline
\end{tabular}

Table 1: Sample descriptives. 


\section{Social Innovativeness}

Continuous renewal and social innovation are important for our company.

We invest heavily in developing new ways to increase our social impact.

In our company, new ideas to solve social problems come up all the time.

Lately we have adopted new ways to serve our beneficiaries.

\section{Social Risk-taking}

We are not afraid to take substantial risks when serving our social purpose.

Bold action is necessary to achieve our company's social mission.

We prefer the cautious line of action even if some social opportunity might be lost that way.

\section{Social Proactiveness}

We aim at being at the forefront of making the world a better place.

Our company often acts before the others do.

We see opportunities where others see only social problems.

Table 2: Scales suggested by the Delphi study. 


\begin{tabular}{|c|}
\hline Social Innovativeness \\
\hline Social innovation is important for our company. \\
\hline We invest heavily in developing new ways to increase our social impact or to serve our beneficiaries. \\
\hline In our company, new ideas to solve social problems come up very frequently. \\
\hline Social Risk-taking \\
\hline We are not afraid to take substantial risks when serving our social purpose. \\
\hline Bold action is necessary to achieve our company's social mission. \\
\hline We avoid the cautious line of action if social opportunities might be lost that way. \\
\hline Social Proactiveness \\
\hline We aim at being at the forefront of making the world a better place. \\
\hline Our organization has a strong tendency to be ahead of others in addressing its social mission. \\
\hline We typically initiate actions which other social enterprises/social entrepreneurs copy. \\
\hline Socialness \\
\hline Core operations \\
\hline The objective to accomplish our social mission precedes the objective to generate a profit (Dees 2001). \\
\hline $\begin{array}{l}\text { Our organization places a strong focus on partnerships with other organizations and/or governments in order to ensure a } \\
\text { greater and accelerated accomplishment of the social mission (Mishra \& Suar 2010). }\end{array}$ \\
\hline Sustainability \\
\hline We measure $\mathrm{CO}_{2}$ emissions and/or our generated waste and actively try to reduce it (Gebauer et al. 2009). \\
\hline $\begin{array}{l}\text { We set ourselves ambitious goals in regard to sustainability and incorporate them in all strategic decisions (Rettab, } \\
\text { Brick, and Mellahi 2009). }\end{array}$ \\
\hline Community \\
\hline $\begin{array}{l}\text { We actively employ socially disadvantaged people (e.g. disabled people, immigrants, elderly people; Graafland et al. } \\
2004 \text { and Gebauer et al. 2009). }\end{array}$ \\
\hline $\begin{array}{l}\text { We support and encourage our employees to get active in voluntary commitments outside of our organization in order to } \\
\text { address social issues (Aupperle } 1984 \text { and Global Reporting Initiative 2013). }\end{array}$ \\
\hline
\end{tabular}

Table 3: Final scales developed from the Delphi study. 


\begin{tabular}{|c|c|c|c|c|c|c|c|c|c|c|c|c|}
\hline \multirow[t]{2}{*}{ Item } & \multicolumn{5}{|c|}{ Descriptive statistics } & \multicolumn{4}{|c|}{ Frequencies } & \multirow{2}{*}{$\begin{array}{l}\text { Sum } \\
\text { score } \\
\text { Value }\end{array}$} & \multicolumn{2}{|c|}{ t-test } \\
\hline & Mean & $\mathrm{SD}$ & Max & Min & Median & 1 & 2 & 3 & 4 & & t-val & $\mathrm{p}(\mathrm{t}-\mathrm{val})$ \\
\hline $\begin{array}{l}\text { Social } \\
\text { Innovativeness } 1\end{array}$ & 1.634 & 0.712 & 3 & 1 & 1.5 & $50.0 \%$ & $36.6 \%$ & $13.4 \%$ & $0.0 \%$ & 194 & -11.017 & 0.000 \\
\hline $\begin{array}{l}\text { Social } \\
\text { Innovativeness } 2\end{array}$ & 1.598 & 0.735 & 4 & 1 & 1 & $53.7 \%$ & $34.1 \%$ & $11.0 \%$ & $1.2 \%$ & 241 & -11.123 & 0.000 \\
\hline $\begin{array}{l}\text { Social } \\
\text { Innovativeness } 3\end{array}$ & 1.720 & 0.774 & 4 & 1 & 2 & $46.3 \%$ & $36.6 \%$ & $15.9 \%$ & $1.2 \%$ & 225 & -9.129 & 0.000 \\
\hline $\begin{array}{l}\text { Social Risk- } \\
\text { taking } 1\end{array}$ & 1.695 & 0.842 & 4 & 1 & 1 & $51.2 \%$ & $31.7 \%$ & $13.4 \%$ & $3.7 \%$ & 231 & -8.660 & 0.000 \\
\hline $\begin{array}{l}\text { Social Risk- } \\
\text { taking } 2\end{array}$ & 1.902 & 0.883 & 4 & 1 & 2 & $39.0 \%$ & $36.6 \%$ & $19.5 \%$ & $4.9 \%$ & 204 & -6.125 & 0.000 \\
\hline $\begin{array}{l}\text { Social Risk- } \\
\text { taking } 3\end{array}$ & 2.110 & 0.861 & 4 & 1 & 2 & $26.8 \%$ & $40.2 \%$ & $28.0 \%$ & $4.9 \%$ & 177 & -4.105 & 0.000 \\
\hline $\begin{array}{l}\text { Social } \\
\text { Proactiveness } 1\end{array}$ & 1.829 & 0.872 & 4 & 1 & 2 & $43.9 \%$ & $32.9 \%$ & $19.5 \%$ & $3.7 \%$ & 214 & -6.964 & 0.000 \\
\hline $\begin{array}{l}\text { Social } \\
\text { Proactiveness } 2\end{array}$ & 1.829 & 0.767 & 4 & 1 & 2 & $37.8 \%$ & $42.7 \%$ & $18.3 \%$ & $1.2 \%$ & 209 & -7.922 & 0.000 \\
\hline $\begin{array}{l}\text { Social } \\
\text { Proactiveness } 3\end{array}$ & 2.049 & 0.830 & 4 & 1 & 2 & $26.8 \%$ & $46.3 \%$ & $22.0 \%$ & $4.9 \%$ & 182 & -4.923 & 0.000 \\
\hline Socialness 1 & 1.744 & 0.886 & 4 & 1 & 2 & $48.8 \%$ & $34.1 \%$ & $11.0 \%$ & $6.1 \%$ & 225 & -7.725 & 0.000 \\
\hline Socialness 2 & 1.890 & 0.817 & 4 & 1 & 2 & $35.4 \%$ & $43.9 \%$ & $17.1 \%$ & $3.7 \%$ & 202 & -6.762 & 0.000 \\
\hline Socialness $3 *$ & 2.561 & 0.931 & 4 & 1 & 2.5 & $12.2 \%$ & $37.8 \%$ & $31.7 \%$ & $18.3 \%$ & 128 & 0.593 & 0.555 \\
\hline Socialness 4 & 1.744 & 0.767 & 4 & 1 & 2 & $42.7 \%$ & $42.7 \%$ & $12.2 \%$ & $2.4 \%$ & 220 & -8.929 & 0.000 \\
\hline Socialness $5^{*}$ & 2.195 & 0.895 & 4 & 1 & 2 & $24.4 \%$ & $39.0 \%$ & $29.3 \%$ & $7.3 \%$ & 168 & -3.085 & 0.003 \\
\hline Socialness $6^{*}$ & 2.171 & 0.953 & 4 & 1 & 2 & $30.5 \%$ & $29.3 \%$ & $32.9 \%$ & $7.3 \%$ & 175 & -3.128 & 0.002 \\
\hline
\end{tabular}

Table 4: Descriptive and decision criteria for the SEO scale items. 


\begin{tabular}{|l|l|}
\hline Dimension & Wording \\
\hline Social Innovativeness 1 & Social innovation is important for our company. \\
\hline Social Innovativeness 2 & $\begin{array}{l}\text { We invest heavily in developing new ways to increase our social impact or to serve our } \\
\text { beneficiaries. }\end{array}$ \\
\hline Social Innovativeness 3 & In our company, new ideas to solve social problems come up very frequently. \\
\hline Social Risk-taking 1 & We are not afraid to take substantial risks when serving our social purpose. \\
\hline Social Risk-taking 2 & Bold action is necessary to achieve our company's social mission. \\
\hline Social Risk-taking 3 & We avoid the cautious line of action if social opportunities might be lost that way. \\
\hline Social Proactiveness 1 & We aim at being at the forefront of making the world a better place. \\
\hline Social Proactiveness 2 & $\begin{array}{l}\text { Our organization has a strong tendency to be ahead of others in addressing its social } \\
\text { mission. }\end{array}$ \\
\hline Social Proactiveness 3 & We typically initiate actions which other social enterprises/social entrepreneurs copy. \\
\hline Socialness 1 & The objective to accomplish our social mission precedes the objective to generate a profit. \\
\hline Socialness 2 & $\begin{array}{l}\text { Our organization places a strong focus on partnerships with other organizations and/or } \\
\text { governments in order to ensure a greater and accelerated accomplishment of the social } \\
\text { mission. }\end{array}$ \\
\hline Socialness 3 & $\begin{array}{l}\text { We set ourselves ambitious goals in regard to sustainability and incorporate them in all } \\
\text { strategic decisions. }\end{array}$ \\
\hline
\end{tabular}

Table 5: Final items of the proposed SEO scale. 